\title{
Identity theory and research in the South African organisational context
}

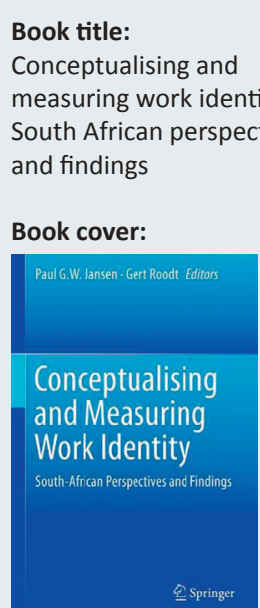

Editors:

Paul G.W. Jansen

Gert Roodt

ISBN:

978-94-017-9241-7/

978-94-017-9242-4 (e-book)

Publisher:

Springer Dordrecht

Heidelberg, New York/

London, ZAR

*Book price unknown at time of review

\section{-}

\section{Review Title:}

Identity theory and research in the South African organisational context

Reviewer:

Melinde Coetzee ${ }^{1}$

Affiliation:

${ }^{1}$ Department of Industrial and Organisational Psychology, University of South Africa, South Africa

Email:

coetzm1@unisa.ac.za

Postal address:

PO Box 392, Preller Street, Muckleneuk, Pretoria 0003 South Africa

\section{Read online:}

Scan this $Q R$ code with your smart phone or mobile device to read online.

\section{Introduction}

Unlocking, engaging and retaining the full potential of all workers on all levels of a post-apartheid culturally diverse South African society towards improved individual work and business performance remains a core challenge for organisations. Released in 2015, Conceptualising and measuring work identity: South African perspectives and findings offers a ground-breaking perspective on the complexities of understanding people's involvement in and attachment to work by introducing the constructs of work identity, identity work and identity formation. The book focuses on conceptualising the constructs within the theoretical frameworks of social identity theory and role identity theory. Identity theory explains people's behaviour as an outcome of the dynamic phenomenon of identity formation and the socially constructed self-concept and role identities that develop within specific socio-environmental structures (Bothma, Lloyd \& Khapova, 2015). The notion of work identity ('Who am I at work?') in reciprocal interaction with the dynamic process of identity work provides a fresh and enticing view on productive and engaging behaviour resulting from a full sense of belonging and identification with one's work, occupation, work setting and employing organisation. The book offers a theoretical framework for operationalising the construct of work identity and a measure of work identity, its antecedents and consequences relating to broadening understanding of employee engagement, attachment and commitment. It further shares empirical findings on the application of the work identity measure as a criterion and predictor and in a structural equation model context (Jansen \& Roodt, 2015, p. vii). In times of global concerns about attracting and retaining scarce and skilled talent, the book is seen as timely in offering deeper insights into the notion of work identity as explaining some of the reasons of why people stay involved in and committed to their employing organisation.

\section{Basic premise of the text}

The book is contextually situated within the historically and contemporary transformational background of the culturally diverse South African society. The basic premise for the work identity project is the search for a new national work identity ('Who am I/are we at work?') that may potentially provide stability in the changing and often turbulent social environment of a postapartheid workplace (Roodt, Jansen \& Crous, 2015, p. 1). Employee and multicultural diversity is seen to compound the challenge of enhancing productivity in the South African workplace. Given the centrality of work in building individual identity, work identity is seen to function as an important mechanism in ensuring the individual's successful integration into heterogeneous work settings by contributing to greater group cohesion, which facilitates individual and collective productivity. The overall objective of the work identity project that culminated in the publication of the book was to 'investigate the impact of work identity on individual performance amongst members of a diverse work force in South Africa' and to provide an integrated model and measure to assist in enhancing South African companies' performance (Roodt, Jansen \& Crous, 2015, p. 7).

In the concluding chapter, Roodt, Jansen and Van de Bunt-Kokhuis (2015, p. 234) posit that the basic premise was successfully achieved by means of the various chapter contributions. The authors conclude that the work identity framework presented in the book could be used to 'develop a unique South African work identity'. The framework may assist in 'creating a more conducive work context for all South African employees and also a much needed shared frame of reference for work-related issues and challenges'. The construct of work identity is seen to provide potential parsimony in commitment-related and engagement-related research by encapsulating various identification constructs and foci. In this regard, the construct of work identity is seen to hold significant methodological potential (Roodt, Jansen \& Van de Bunt-Kokhuis, 2015, pp. 239-240).

How to cite this book review: Coetzee, M. (2015). Identity theory and research in the South African organisational context. SA Journal of Industrial Psychology/SA Tydskrif vir Bedryfsielkunde, 41(1), Art. \#1282, 2 pages. http://dx.doi.org/10.4102/sajip.v41i1.1282

Copyright: (C) 2015. The Authors. Licensee: AOSIS OpenJournals. This work is licensed under the Creative Commons Attribution License. 


\section{Structure, content and style of the text}

Chapter 1 provides a well-rounded background to the work identity project and its objectives and includes an outline of the book structure. The text is partitioned into four parts. Part I of the book provides the conceptualisation and theoretical foundations of work identity (Chapter 2) followed by qualitative research that outlines a model for explaining identity work and the tactics and strategies applied to maintain and enhance work identity (Chapter 3). Part I further explores job demands and job resources as possible antecedents of work identity (Chapter 4) and, in Chapter 5, reviews the subjective and objective consequences of work identity. Part II (Chapter 6) provides empirical research findings of two South African quantitative studies on the operationalisation and measurement of work identity whilst Part III (Chapter 7) offers insights into causality, assessed by means of structural equation modelling. Part IV critically reviews the research findings and specific contributions of the work identity project and states conclusions on the empirical results (Chapter 8). Finally, in Chapter 9, practical implications of the project outcomes are highlighted and suggested recommendations for future research are provided.

Stylistically, the theoretical premises and viewpoints in each chapter are critically reviewed and well-substantiated by theory and the research literature. Although written in an academic discourse style, the text is easy to follow and often illustrated by relevant real-life case examples. Overall, the authors manage to explain and discuss a complex construct with relative ease.

\section{Conclusion}

Conceptualising and measuring work identity: South African perspectives and findings extends theory and research on employee performance, engagement and commitment by introducing the dynamic construct of work identity. The theoretical conceptualisation of the construct is operationalised by means of a measure of work identity, which holds promising new avenues for research in the postapartheid South African multicultural organisational context. The book will undoubtedly continue to yield valuable insights for academia, researchers and practitioners in the field and as such deserves a place in the organisational behaviour library.

\section{Acknowledgements Competing interests}

The author declares that she has no financial or personal relationships that may have inappropriately influenced her in writing this article.

\section{References}

Bothma, F.C., Lloyd, S., \& Khapova, S. (2015). Work identity: Clarifying the concept. In P.W.G. Jansen \& G. Roodt (Eds.), Conceptualising and measuring work identity: South African perspectives and findings (pp. 23-52). Dordrecht: Springer. http:// dx.doi.org/10.1007/978-94-017-9242-4_2

Jansen, P.W.G., \& Roodt, G. (2015). Preface. In P.W.G. Jansen \& G. Roodt (Eds.), Conceptualising and measuring work identity: South African perspectives and findings (p. vii). Dordrecht: Springer. http://dx.doi.org/10.1002/cad.20090

Roodt, G., Jansen, P.W.G., \& Crous, F. (2015). Introduction: What this book is all about. In P.W.G. Jansen \& G. Roodt (Eds.), Conceptualising and measuring work identity: South African perspectives and findings (pp. 1-22). Dordrecht: Springer. http:// dx.doi.org/10.1007/978-94-017-9242-4_1

Roodt, G., Jansen, P.W.G., \& Van de Bunt-Kokhuis, S. (2015). Moving forward Practical and theoretical implications. In P.W.G. Jansen \& G. Roodt (Eds.) Conceptualising and measuring work identity: South African perspectives and findings (pp. 233-248). Dordrecht: Springer. http://dx.doi.org/10.1007/978-94017-9242-4_9 